\title{
lowa Writers and Painters: An Historical Survey
}

Leland L. Sage

IN EARLY OCTOBER, 1914, the Iowa Press and Authors' Club sponsored a "Homecoming of lowa Authors" in Des Moines, a gathering which was somebody's idea of demonstrating that lowa could produce something besides corn, hogs, and politicians. Among the distinguished writers on the invited list were Hamlin Garland, Emerson Hough, Rupert Hughes, Edna Ferber, Herbert Quick, Susan Glaspell, Alice French (Octave Thanet), and Albert Bigelow Paine, a biographer of Mark Twain. ${ }^{1}$

It is not a matter of public record whether this was an open or closed meeting, or what credentials were required for admission into the charmed circle. Was Hamlin Garland challenged on the grounds of birth in Wisconsin, or on the grounds that he had spent only thirteen years of his life in lowa? Was Octave Thanet challenged on the ground of birth in Andover, Massachusetts, even though she was brought to Davenport at the age of six, grew up with the town, and always counted it her home? These questions, and others soon to be raised, are not altogether idle musing. Not the least important consideration for one attempting an essay on a state's cultural history is the setting of criteria for determining state citizenship. What, then, is an lowan?

Various scholars have come up with varying answers, implied or

\footnotetext{
${ }^{1}$ Des Moines Register and Leader, October 4, 6-8, 1914; James B. Weaver, "The Authors' Homecoming of 1914," The Midland, 1 (January, 1915), 22-25. Iowa's claim on Albert Bigelow Paine, and vice versa, was a slight one; he lived in Bentonsport when he was aged 1-5. His rating as a Twain scholar is very low. See Dictionary of American Biography, 22:509; Des Moines Register, October 22, 1972, for an article on current Twain scholarship at the University of lowa which will correct some of Paine's mistakes.
}

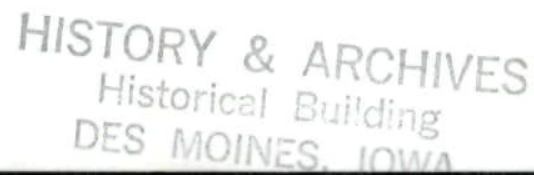


specific, to this question. In 1918 Alice Marple of the State Historical Department compiled a much too inclusive list of lowa authors, seemingly including every writer who had ever set foot in lowa. Johnson Brigham, himself a transplant to lowa at the age of thirty-five, put togehter a series of essays by himself and others, entitled $A$ Book of lowa Authors by lowa Authors, ${ }^{2}$ not bothering to state his criteria for selection. Early in his career Wallace Stegner wrote an essay on lowa authors, admitting to his list those who were of lowa birth and upbringing, or who had spent enough time in the state to be "indelibly" marked by the environment. ${ }^{3}$ Frank Paluka, curator of the Special Collections in the University of lowa Libraries, in by far the most authoritative study yet to appear, used two criteria in making up his list: birth in lowa, and publication of five or more books. ${ }^{4}$ Yet Paluka questions his own criteria when he points out that his tests exclude on grounds of birth such notable authors as Hamlin Garland, Octave Thanet, Rupert Hughes, and Cornelia Lynde Meigs, and on quantitative grounds such lowa-born writers as John T. Frederick, Ferner Nuhn, Mona Van Duyn, and several others. On the other hand his requirements serve to admit certain persons of limited attachment to lowa, notably Herbert Hoover, who until the end of his life never thought it appropriate to claim status as an "lowan."

Place of birth is itself of little importance and of itself does not operate to make a person a true lowan, Nebraskan, Kentuckian, or New Yorker, nor does residence itself perform a similar function. ${ }^{5}$ Wisconsin writers have claimed Carrie Chapman Catt simply on the basis of her birth near Ripon, though she was brought to lowa as a small child, educated here, and worked in Mason City for many

${ }^{2}$ Alice Marple, compiler, lowa Authors and Their Works (Des Moines: lowa Historical Department, 1918); Johnson Brigham, A Book About lowa Authors by lowa Authors (Des Moines: lowa State Teachers Association, 1930).

${ }^{3}$ Wallace Stegner, "The Trail of the Hawkeye: Literature Where the Tall Corn Grows," Saturday Review of Literature, 18 (July, 1938), 3-4, 16-17.

${ }^{4}$ Frank Paluka, lowa Authors: A Bio-Bibliography of Sixty Authors (Iowa City: Friends of the University of lowa Libraries, 1967), p. vii. Paluka, pp. 217-220, gives biographical data and a bibliography for Wallace Stegner. It is with regret that $I$ do not feel that lowa is fully justified in claiming this excellent writer. He was born in Lake Mills but spent only a short time there.

${ }^{5}$ For a humorous poem on this subject, see Archibald MacLeish, "Where A Poet's From," Saturday Review of Literature, 50 (December, 1967), 21; another clever jab is in Donald Kaul's column, "Over the Coffee," Des Moines Register, March 6, 1967. 
years. Surely lowa "indelibly" influenced her though she rose above the claim of any one state or even nation as she became a world citizen working for peace and disarmament. Carl Van Vechten is a case in reverse. Though born in Cedar Rapids and reared and educated there, he became a banker, musicologist, and novelist in New York and abroad, whose only novel dealing with lowa, The Tattooed Countess (1924), was an exercise in ridicule of his former home. $^{6}$

In this brief essay, the simple test will be: has a novelist, poet, or painter, regardless of his place of birth, lived in lowa a sufficient time to regard it as his residence, or long enough to be influenced in some demonstrable way by his lowa sojourn, and has he produced a sufficient amount of artistic or scholarly work to have won recognition by his peers and by the public? Perhaps each case will have to be decided on its own merits.

\section{Early lowa Novelists: Hamlin Garland and Others}

If Hamlin Garland may be claimed in part for lowa, a claim not at all far-fetched in view of the very active and joyful part which he took in the aforementioned Des Moines meeting of lowa authors, he should be called the first lowa writer worthy of notice. Born in West Salem, Wisconsin, on September 14, 1860, he moved with his parents in 1867 to an Iowa farm near Hesper, and then to one near Burr Oak, both Winneshiek County hamlets, and then to a Mitchell County farm near Osage in 1869. Here his parents searched for greener pastures than the coulee country east of La Crosse which the boy loved so well and to which he returned as a man of property when success came his way. In these lowa communities he pursued his formal education in country schools and in the Cedar Valley Seminary in Osage. For some thirteen formative years he lived in lowa, mixing school with a man's work on the farm and attaining his majority while here, surely sufficient time to give lowa a valid though not exclusive claim on him.

The typical experiences of South Dakota homesteading and the vicissitudes of prairie farming did little to improve the young man's fortunes but added to the formal and informal education he had received in lowa and elsewhere. The sum total of all these

\footnotetext{
'Paluka, lowa Authors, pp. 52-56, gives biographical details and a bibliography of Van Vechten's works.
} 
experiences constituted the storehouse on which he would draw for his writing. With great relief he sold out and fled eastward to study, and then to teach, elocution at the Boston School of Oratory, and for several years had the exhilarating and instructive experience of living in Boston, ${ }^{7}$ a strange contrast, indeed, to his previous experiences.

His first writing of any consequence, Main-Travelled Roads (1891), dealt with the thing he knew best: farm life on the raw frontier of the West, as he had observed it and lived it in Wisconsin, lowa, and South Dakota. This book and others that followed gave a realistic view of farm life which had seldom been presented to the American public. Garland is grouped with Edward Eggleston and Joseph Kirkland in the vanguard of writers who turned against those who tried to romanticize farm life. Instead of "naturalism," the word then in vogue, he called his style "veritism," a coinage intended to imply more than mere objective realism. His keen awareness of the farmers' problems led him to join the Peoples Party and campaign in its behalf.

After some years of effort to write outside of his experience, he returned to the scene of his youth for his material. The resulting book, A Son of the Middle Border (1917), was his best book but failed to win the Pulitzer Prize, a bitter blow. The sequel, $A$ Daughter of the Middle Border, with enough attention to his mother to justify the title, won the coveted prize. The second book was without doubt inferior to the first, even a fiasco. His latest biographer avers that there was considerable backstage maneuvering among the judges, in which Garland took some part, and delivers the dictum that the 1921 award was a tardy recognition of Garland's A Son of the Middle Border. After 1921 came a few potboilers and some experimentation in writing for motion pictures. He spent his declining years in Hollywood, where he died on March 4, 1949. ${ }^{8}$

\footnotetext{
${ }^{7}$ These biographical details are put together from several sources, not least Hamlin Garland's own writings, even though they are at times a bit hazy on chronology. A recent effort at clearing up some questions as to residence and chronology is reported in Thomas G. Schuppe, "Hamlin Garland of lowa," Annals of lowa (Winter, 1972), 843-67.

${ }^{8}$ Jean Holloway, Hamlin Garland: A Biography (Austin: University of Texas Press, 1960), pp. 242, 254-258. I am much indebted to Miss Emma Diekroeger of the La Crosse Public Library, and Mrs. Rachel Gullickson of West Salem, Wisconsin, for the opportunity to draw on their collections of Garlandiana.
} 


\section{Octave Thanet}

A contemporary of Hamlin Garland, like him an adopted Iowan but of much longer residence in lowa, was Alice French of Davenport (1850-1934), better known then and now as Octave Thanet. Like most of the lowa writers of the pre-1920 period, she is little known except to literary historians and practically unknown to the general reader born after 1930. Her fall from fame to nonentity is well covered by the descriptive title employed by her latest biographer, Journey to Obscurity. Our generation may scoff but in her prime she was lauded by the best critics of her day, including William Dean Howells, and for thirty years she was in the charmed circle of best sellers, which made her one of the best paid writers in the country. Her biographer indicates that she and other "writers of local color, especially the literary women who were a large and effective part of the movement, are most valuable as indices to the taste and culture of their times and to the range of American culture." ${ }^{\prime 9}$ Granted that she has no message for this generation, she deserves her brief walk across the stage of lowa history.

Member of a rich and prominent family, she showed her own independent spirit by dropping out of Vassar College's preparatory department after only one semester, in protest against the superficial thinking of some of her classmates about the problems of life. This tendency towards protest frequently asserted itself as she became interested in the causes of the day.

A very prolific writer during the height of her powers, like Hamlin Garland she spread herself too thin. Her interest in the causes of the day, her health problems, her travels in search of relief from crippling arthritis, and financial difficulties culminating during the financial debacle of 1929, led to a dissipation of her energies and talents. It was just as well. A public which had turned to Ernest Hemingway, F. Scott Fitzgerald, and Sinclair Lewis, had little time for the exaggerated local colorist technique by which she sought realism, but without the courage to avoid happy, romantic endings. Perhaps there is little profit in reading her works today but her career is an interesting example of a talent, far short of genius, to be sure, which was used in constructive ways, at least according to her

\footnotetext{
${ }^{9}$ George McMichael, Journey to Obscurity: The Life of Octave Thanet (Lincoln: University of Nebraska Press, 1965), p. 2; passim.
} 
own lights. The curious reader who wants to check up on her art should try her short story, "Communists and Capitalists: A Sketch from Life," and her novel, By Inheritance, a study of the Negro problem as it appeared to the thinking people of 1910, reaching conclusions a million light years away from those of the 1970s. These are her best works, in the opinion of an able critic-historian of lowa literature. ${ }^{10}$

\section{Herbert Quick}

As Hamlin Garland and Octave Thanet were beginning to fade out of the picture in the early 1920s, the reading public turned to their successor, though not for long. The man who moved to down stage center was Herbert Quick. Passing over his earlier work in silence, it is as the author of three novels and an autobiography, all published in rapid succession, that he won a lasting place in lowa literary history: Vandemark's Folly (1922), The Hawkeye (1923), The Invisible Woman (1924), and One Man's Life (1925). Never at the top of the list of best sellers, the books are read now by those who have a definite love of frontier history, a desire to recapture a picture of frontier lowa.

Herbert Quick was born in 1861 on a Grundy County farm near the Hardin County hamlet of Steamboat Rock. Crippled by polio in childhood, he supplemented his country schooling by reading everything that came his way, good or bad. Spared the hardest forms of farm work by his illness, he nevertheless knew from hearsay and by observation every detail of the saga of migration from the East (his parents came out to lowa from New York) and the process of breaking and draining the prairie sod. All this lore he stored lovingly in his mind, starting as a boy to dream of the day when he could put it all together in story form. Eventually his dream would come true but not until he had waited some fifty years. In the meanwhile he read law, won admission to the bar, and practiced for fifteen years in Sioux City, where he served a term as mayor. He left the security of his established practice to try his hand at journalism and occasional ventures into fiction. He worked a short time on the editorial staff

\footnotetext{
${ }^{10}$ Clarence A. Andrews, "A Patrician Who Tried To Face Reality," The lowan, 18 (Winter, 1969), 26-27, 50-54, an excellent brief study. My article was completed before the appearance of Clarence A. Andrews' A Literary History of lowa (lowa City: University of lowa, 1972).
} 
of La Follette's Weekly Magazine and then eight years as editor of Farm and Fireside. During these years he contributed articles on farm problems and municipal government to the Saturday Evening Post. These accomplishments of a self-educated lowa farm boy indicate that here was a person of far more than ordinary learning and literary ability.

Through all these years as lawyer and editor he published many small-caliber stories and books, always weakening his appeal by his inability to suppress his instincts towards reform and uplift. Such interests, subsumed under his political label of "progressive Democrat," enabled him to win recognition as a writer on public affairs, especially the farm problems of overproduction and lack of seasonal credit. As co-author of the 1916 plan for federal farm loan banks to make direct loans to farmers and farm groups, he won the notice of President Wilson who appointed him to the Federal Farm Loan Board. After three years of effective contribution to the alleviation of the farm problem, he again retired from public life and secure position, this time to settle down on an apple farm at Berkeley Springs, West Virginia, to write a long-planned trilogy on the lowa farm story, from the first settlements to his own day. His work was interrupted by a call to Red Cross work in Russia, and while there an attack of bleeding ulcers made him despair of living. His life was spared and the plans he had made for a friend to finish the first volume of his work could be cancelled. The book appeared in 1922 as Vandemark's Folly, followed by the three books listed above.

As fiction the books are seldom read by this generation but they have much of value as frontier history and as farm and nature studies. The beauty of the virgin prairies, the reclamation of the land, the ravages of prairie fires and the devastation wrought by storms and blizzards, have been vividly described. Herbert Quick did for lowa what Hamlin Garland did for a region: he demonstrated that an lowa farm scene and its extension, the small county seat town ("Monterey Center" is, of course, Grundy Center), could be peopled with characters whose lives were just as much worth writing about as people in any other locality. His description of pioneering was written without apology about the lowa he knew as a boy and which he never forgot despite his wide travels. That his artistry was inferior to a Willa Cather's or a Rolvaag's may be readily granted, but for a man sixty years of age to have the courage to set himself to 
such a task and the intellectual power to carry it out, deserves the unmixed tribute of later generations. ${ }^{11}$

Other Novelists of the 1920s-1930s

Very much in the Hamlin Garland-Herbert Quick tradition of greater emphasis on plot than on character, are two lowa writers who enjoyed great popularity in the 1920 s, with a slight carry-over into the 1930s: Margaret Wilson (1882- ) and Bess Streeter Aldrich (1881-1954), the former even attaining the fame that goes with winning the Pulitizer Prize for the best novel of the year, an honor bestowed on her for her 1923 book, The Able McLaughlins. Unfortunately, the winning of the Pulitzer Prize does not always guarantee excellence, as an astute scholar has recently shown. Born in Traer, a niece of "Tama Jim" Wilson, Secretary of Agriculture under McKinley, Roosevelt, and Taft, Margaret Wilson was well equipped by both inheritance and training to tell the familiar story of immigrant farmers, in this case Scots, who came to America and made such outstanding contributions to our economy and our culture. Perhaps The Able McLaughlins and her later novels have not held up in the fierce competition for the public's favor, but it must be asserted that she helped a generation of twentieth century Americans to see what sacrifices were necessary if the western frontier were to be subdued. ${ }^{12}$

Bess Streeter Aldrich, like Margaret Wilson, is now a lightly-

${ }^{11}$ The best source on Herbert Quick is his autobiography, One Man's Life (Indianapolis: Bobbs-Merrill Co., 1925); also of great value is Allan G. Bogue, "Herbert Quick's Hawkeye Trilogy," Books at lowa (lowa City: The University of lowa, April, 1972), 3-13. I am much indebted to Professor Bogue for an opportunity to see his essay prior to publication. Also see Roy W. Meyer, The Middle Western Farm Novel in the Twentieth Century (Lincoln: University of Nebraska Press, 1965), pp. 47-56.

${ }^{12}$ W. J. Stuckey, The Pulitzer Prize Novels: A Critical Backward Look (Norman: University of Oklahoma Press, 1966), pp. 47-48. Professor Stuckey calls The Able McLaughlins a "derivative" book but asserts "her models were not the social histories of H. G. Wells or John Galsworthy" but rather [she] "drew on the native tradition of local color and the fictional tragedies of Thomas Hardy." He admits that Miss Wilson is good on such things as "furniture, meals, prayers, building of houses, poor roads, the hard life of women, the stubbornness of men," but the book is "amateurish," lacking unity, using realism for its own sake, and dependent on a contrived love triangle. Paluka, lowa Authors, pp. 63-64, gives biographical and bibliographical facts. 
regarded author. Although most of her writing was done after she had settled in Nebraska, it is permissible for lowa to assert a partial claim on the basis of her birth in Cedar Falls and her long years of residence there, and the lowa setting of many of her books and short stories, which faithfully reflect her background. Born in 1881 of pioneer stock who attained political prominence and economic and social success, as a girl and young woman she never knew anything but the comfort and security of a prosperous middle-class, midwestern home. As a student in the lowa State Normal School in her home town, she took the Primary Course, preparing for a career as a teacher of little children. After a short teaching career and marriage in 1907, her lowa residence ended when she and her banker-husband moved to Elmwood, Nebraska, where for many years she knew nothing but a life of small-town affluence, with a busy role as mother, homemaker, church worker, and social leader in this farming center near Lincoln in eastern Nebraska.

Her professional writing career began in a small way, shortly before her husband's untimely death in 1925. Of the seven novels and some 160 short stories which she wrote between 1924 and 1942, only three of the novels could be said to have enduring interest: A Lantern In Her Hand (1928), White Bird Flying (1931), and Song Of Years (1939), although some would insistently add Miss Bishop (1933). The first three tell the story of the toil and hardships, the sacrifices, the triumphs and defeats of the men and women who settled in lowa and Nebraska; Miss Bishop is the story of a teacher who finds her reward in the successes of her pupils.

These and all the rest of the books and short stories were the products of a passion for writing that would not be denied in spite of many rejection slips and merciless criticism from reviewers who were more attuned to the new realism than to the gentle, ultra-Victorian style of Mrs. Aldrich. To these barbs she made her own reply: ". . . the trend, of course, has been to write of the fast, high-strung, disintegrating home. That type of home is as American as the type I write about, but no more so. It no more represents all of America than does my type. But it is heard from more than the type I represent." 33 For the record it should be added that a sizable

${ }^{13}$ Lillian V. Lambert, "Bess Streeter Aldrich," in Johnson Brigham (ed.), A Book of lowa Authors, pp. 17-30; A. Mabel Meier, "Bess Streeter Aldrich: A Literary Portrait," Nebraska History, 50 (Spring, 1969), 67-100. Roy W. 
segment of the American reading public endorsed Mrs. Aldrich's view of life by purchasing her books and stories and attending the motion pictures based upon them, all of which enabled her to lay by a tidy sum. Her last book, The Lieutenant's Lady, appeared in 1942.

Three novelists who belong to the Garland-Octave Thanet-Quick era deserve only brief mention here because they related to lowa in only a small way. Emerson Hough (1857-1923), a native son of Newton, was a prolific writer of novels and short stories of fleeting popularity-Herbert Quick considered him and Hamlin Garland as his chief competitors for the favor of the American reader. Even in his own day he was criticized for his looseness with historical facts and his pedestrian style; today he is an unknown. The Covered Wagon is undoubtedly his best work; Fifty-Four Forty or Fight ranks second. Rupert Hughes (1872-1956) produced a shelfful of novels and short stories which were popular enough to make his name a household word and his home in Keokuk an attraction for sightseers. As the holder of a graduate degree in history from Yale University he was the author of a respectable three-volume biography of George Washington; he was also a bit of a musicologist. Ellis Parker Butler (1869-1930) of Muscatine and New York, gained fame as a humorist with a little thing, now mercifully forgotten, called Pigs Is Pigs (1906); books for boys and girls, and a very good novel in the form of a biographical essay about a minister in Muscatine, Dominie Dean (1917), make up a better claim for remembrance. ${ }^{14}$

\section{John T. Frederick and the Second Generation of lowa Writers}

Hamlin Garland had introduced a note of realism into writing about the Middle West, and the next generation of writers inevitably turned to new themes or new angles of old themes, treating them with greater realism, with more highly developed artistry, and with a greater awareness of regional consciousness. Although not all of the "lowa" writers of this era came under the guidance of John Towner

Meyer, The Middle Western Farm Novel, pp. 68-69, discounts Mrs. Aldrich's books, A Lantern in Her Hand and Song of Years, saying that they "contribute nothing essentially new to the story of pioneering in lowa and Nebraska .... and are marred by sentimental plots and much bad writing."

${ }^{14}$ See Alvin F. Harlow, "Emerson Hough," DAB, 9:250; on Rupert Hughes, see New York Times, September 10, 1956; on Ellis Parker Butler, see the essay in A Book of lowa Authors, pp. 33-42. 
Frederick, it would be hard to set limits to the influence of this man in the creation and development of a striking new phase of literature, some of which we may call "lowa" literature.

While yet an undergraduate at the University of lowa, the young man from Corning, prominent in student journalism and forensics, founded a literary magazine, The Midland, the very name suggesting a regional point of view, not the outlook of a state sufficient unto itself. In a way the new journal was a successor to Johnson Brigham's Midland Monthly, long since defunct. The first number appeared in 1915, at a time when the "giants" such as Garland and Octave Thanet were still prominent and Herbert Quick was several years away from his fame, but it is evident that this young dreamer was thinking of new departures in the realm of lowa literature and other forms of art. No commentary on John Frederick would be complete without a partial quotation from the editorial credo to which he subscribed, even though the actual words were written by another hand:

\begin{abstract}
The magazine is merely a modest attempt to encourage the making of literature in the Middle West. The region is already renowned for certain material products and for financial prosperity; but the market of its literary and other artists has commonly been beyond the mountains, and the producers have commonly gone to their market. Possibly the region between the mountains would gain in variety at least if it retained more of its makers of literature, music, pictures, and other forms of civilization. And possibly civilization itself might be with us a somewhat swifter process of expression if its spirit were more frequent. ... ${ }^{15}$
\end{abstract}

From 1915 to 1934 The Midland flourished-or at least stayed alive. It was not narrowly "Iowan" but Midwestern. Its publication office might be any one of several places as it followed the young editor in his travels. Interspersed in his years of graduate study, teaching, and the periods devoted to his own writing, were intervals occupied by actual dirt-farming, near Glennie, Michigan. Born close to the soil on a farm near the southern lowa town of Corning, in 1893, John Frederick believed that the periods given over to farming

${ }^{15}$ The Midland, 1 (January, 1915), 1-2. Actually, this statement was written anonymously by Professor Clark F. Ansley, head of the Department of English, University of lowa, according to Lois T. Hartley, "The Midland," lowa Journal of History and Politics, 47 (October, 1949), 325, who says that John T. Frederick gave her this information. 
and contact with the soil are his sources of intellectual and artistic replenishment.

Even though a successful novelist, poet, and short story writer, probably his greatest gift to lowa and the world has been his recognition and encouragement of young talent. His genius for assisting young writers is nothing short of uncanny, so much so that we are justified in speaking of a Frederick school of writing. His firm constructive criticism has helped many beginning writers to find themselves. His role as editor, critic, teacher, counsellor, and confidant proceeds from the mind of a doer, not a preacher: Druida (1923) and Green Bush (1925) are good solid novels; his short stories and poems, too numerous to mention here, have met with critical approval. Recently he has turned to advanced historical criticism in a major work. The Darkened Sky, a study of the religious ideas of Cooper, Hawthorne, Melville, Twain, Howells, and Henry James, followed by an appreciation of W. H. Hudson.

Consider the authors whose names first appeared in The Midland at Frederick's invitation and whose early work was given exposure in its pages: Ruth Suckow, Walter Muilenburg, Nelson Antrim Crawford, Irving Brant, Roger L. Sergel, Mark Van Doren, Paul Engle, Marquis Childs, James Hearst, MacKinlay Kantor-the list goes on and on. Fortunately, this demonstration of the possibilities of creative writing in lowa was followed by the organization of the School of Letters in the University of lowa in the early 1920s, under the direction of Professor Norman Foerster, a move which led to the establishment of a Program in Creative Writing ("Writer's Workshops") in the Department of English, one of the truly distinctive contributions of the University to educational theory and practice. In this program, poems, plays, short stories, and novels have been made acceptable, quality permitting, as masters' theses and doctoral dissertations, often followed by publication as articles or books. Somewhere in this chain of evolution at least one link is inscribed with the name of John Towner Frederick. ${ }^{16}$

16 Lois T. Hartley, "The Midland," 325-344; John T. Frederick, The Darkened Sky: Nineteenth Century American Novelists and Religion (Notre Dame: University of Notre Dame Press, 1969). In 1963, Professor Frederick resumed teaching at his alma mater, and held the post until 1970. For a recent appreciation of his writing and his teaching, see Sargent Bush, Jr., "The Achievement of John T. Frederick," Books at lowa, No. 14, April, 1971, pp. 8-30. 


\section{Ruth Suckow}

The first member of the new school of writers to achieve worldwide renown was Ruth Suckow, a writer whose own personal story is so interesting and so remarkable that it can be adequately presented only in a full-length biography or in extended fictional treatment (as it was here and there in several of her novels). She was born in 1892 in the little town of Hawarden, the daughter of parents of German-American lineage of superior intellectual interests and attainments. Her father, although usually called to small parishes with small salaries, was a Congregational minister of more than average abilities. Somehow he was able to assist his two daughters with their college educations, Emma at Grinnell College, and Ruth at Grinnell, 1910-1913, then two years at the Curry School of Expression in Boston, then at the University of Denver.

In 1918 The Midland published her four-line poem, "Song in October," since widely anthologized. It is not difficult to understand how this shy, studious girl of delicate temperament won the approval of her professors at Grinnell and Denver and an appointment from John Frederick as his assistant editor on The Midland. But her ability to win recognition, acceptance, and encouragement from that ebullient, tough-minded, brilliant cynic, H. L. Mencken, editor of The Smart Set, the most advanced literary magazine in the country, is indeed a study in extremes. Not only did Mencken publish her short novel, "A Part of the Institution," and several short stories; he voluntarily and enthusiastically called her work to the attention of his publisher-friend, Alfred A. Knopf, who published her first novel, Country People, in 1924. Mencken also sent her work to Sinclair Lewis, who supported Mencken's enthusiasm for the lowa girl. For the first number of his new magazine, The American Mercury, appearing in January, 1924, Mencken gave her the honor of a choice spot for her short story, "Four Generations," which he called the best short story she had ever written. Three years later he was putting her in the same class with James Joyce, Eugene O'Neill, and Theodore Dreiser.

In the following years books and short stories poured from her pen: The Odyssey of a Nice Girl (1925), lowa Interiors (1926), The Bonney Family (1926), Cora (1929), The Kramer Girls (1930), Children and Other People (1931), The Folks (1934), Carry-Over (1936), which was a reprint of Country People and The Bonney 


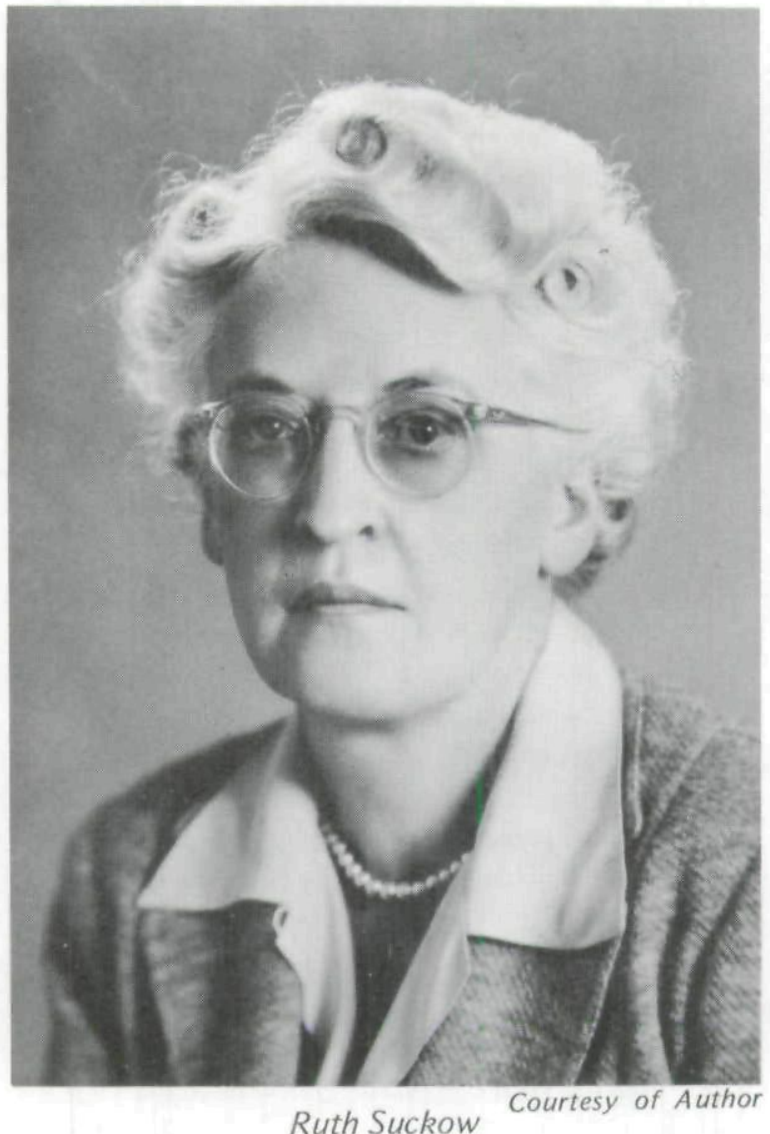

Family, plus sixteen new short stories; New Hope (1942), Some Others and Myself: A Memoir (1952), three beautiful short stories plus an essay about her experiences as a minister's daughter and her own religious beliefs, cast in the form of an intellectual biography of her father; and, finally The John Wood Case (1959).

Such a listing of her writings, impressive as it is, does not begin to do justice to her full life as a lecturer and teacher, member of President Franklin D. Roosevelt's Commission on Farm Tenancy, wife, citizen, student of religion, worker for The American Friends Society, counselor to young writers, and author of countless other unknown good works unobtrusively performed. Only her rigorous working schedule as a writer prevented her from doing more in the 
public realm. A severe attack of arthritis necessitated a move in 1951 from her lowa home in Cedar Falls to Tucson, and to Claremont, California, where she died on January $23,1960 .^{17}$

\section{Susan Glaspell}

One of the brightest stars in the lowa galaxy is Susan Glaspell, whose interests and activities led her far from lowa at times, yet whose career owed much to lowa contacts and influences. Her career easily divides itself into three parts. Born in Davenport in the late 19 th century and growing up in the era when that city's literary circle was the most outstanding in the state, featured by Octave Thanet's nationwide popularity, she was not without inspiration and guidance. After graduation from Drake University in 1899, she successively worked as a reporter for newspapers in Des Moines, took advanced work at the University of Chicago, wrote short stories about Davenport, and otherwise busied herself in a long and serious apprenticeship for a writing career. This, the first part of her life story, was climaxed by the publication of two novels, The Glory of the Conquered, in 1909, followed two years later by The Visioning.

The second and most notable part of her career was only distantly if at all related to lowa but deserves brief narration here because of its contribution to American culture. In 1913, shortly after her marriage to George Cram Cook, a talented but eccentric member of a pioneer family of Davenport, she and her husband summered in Provincetown, Massachusetts, where they founded the experimental theatre known as the Provincetown Players. Very informally organized and managed, the principal purpose of the enterprise was to provide an outlet for original one-act plays written by one or another of the founders or sometimes jointly, or by other members of the summer colony. Eugene O'Neill became the principal author in the group. During the winter season they lived in New York and in September, 1916, Cook, John Reed, and their associates organized the Playwright's Theatre in Greenwich Village.

\footnotetext{
17 Leedice McAnelly Kissane, Ruth Suckow (New York: Twayne Publishers, Inc., 1969), passim; H. L. Mencken, Letters of H. L. Mencken, selected and annotated by Guy J. Forgue (New York: Knopf, 1961), pp. 227, 230-231, 233, 256, 258, 298-299; Lois B. Muehl, "Ruth Suckow's Art of Fiction," Books at lowa, No. 13, (November, 1970), pp. 3-12; Ferner Nuhn, "The Orchard Apiary': Ruth Suckow in Earlville," The lowan, 20 (Summer, 1972), 21-4, 54.
} 
For several years the emphasis was on production of experimental plays, and out of this the "Little Theatre" movement in America was born. The fact that the Playwright's Theatre and several other little theatres were gradually replaced by larger, more commercialized enterprises, does not mean that the Little Theatre movement failed: it was rather proof of its success. Momentarily disenchanted, however, by the seeming failure of their project, the Cooks went to Greece in search of the perfect culture, a search which failed, of course, but during which Cook became a hero to Greek intellectuals. In 1924 George Cram Cook died and Susan Glaspell returned to America. In 1927 she published a biography of her husband which was not only a tribute to him but a history of their combined activities in the American theatre.

Any literary activity after this would belong to the third phase of Susan Glaspell's career. Although remaining in the East, she was definitely under the influence of her midwestern background, a statement for which we have the highest authority, Miss Glaspell herself. Perhaps this is not wholly true of her play about Emily Dickinson, "Alison's House," for which she received the Pultizer Prize and the accolade of everyone who had a place in the American theatre, but it is clearly true for the novels which followed in quick succession: Brook Evans (1928), Ambrose Holt and Family (1931), The Morning Is Near Us (1939), Cherished and Shared of Old (1940), Norma Ashe (1942), and Judd Rankin's Daughter (1945). Only a reading of these novels could do justice to Miss Glaspell's point about the influence of the Midwest on her work: "I have never lost the feeling that that is my part of the country." Rightly or wrongly, she believed that the Midwest and its people had certain values that were not to be found elsewhere, and it is this belief which she presents in the novels listed above. ${ }^{18}$

\section{MacKinlay Kantor}

MacKinlay Kantor is probably lowa's most prolific novelist and one of her most highly regarded authors. Born in Webster City in 1904, he began his writing career as a seventeen-year old high school journalist. Two years as a free lance writer in Chicago, a short stint as a reporter for the Cedar Rapids Republican (1927), more free

\footnotetext{
${ }^{18}$ Arthur E. Waterman, Susan Glaspell, (New York: Twayne Publishers,
} Inc., 1966); Floyd Dell, "George Cram Cook," DAB, 4:372. 
lancing while writing two Chicago-based novels of small consequence, then a year or more as a columnist for the Des Moines Tribune, and a brief experience as a scenario writer in Hollywood, served him as a writing school.

Although it was apparently as a poet that Helen Cowles LeCron wrote of him and James Hearst in 1930, as the two young lowa writers of greatest promise, ${ }^{19}$ he had already made the decision to devote himself to fiction. By 1934 his long years of journalism, anonymous authorship of penny-a-word stories for the pulp magazines, and years of immersion in the study of the American Civil War, began to yield fruit. In that year his first of many books with a Civil War theme appeared: Long Remember, obviously built around the Battle of Gettysburg. More popular was the beautiful story, The Voice of Bugle Ann (1935). From this point onward a wide variety of books, short stories, verse, and articles poured from his pen, with time out for combat experience as a flyer in World War II, and always the continuing study of Civil War history. The original story for "The Best Years of Our Lives," a post-World War II drama, was a challenge to the moving picture industry to rise above mere entertainment. The supreme reward, however, for some thirty-five years of disciplined study of the Civil War and constant self-criticism of his writing came in the form of the triumph of his vast opus, Andersonville, completed in 1953 and published in 1955, and awarded the Pulitzer Prize in 1956 for the best novel of the preceding year.

On the face of it nothing would seem more unlikely than the prospect of a readable yet historically valid story about the horrors of life in this infamous Confederate prison. Objection has been made to the classification of the book as a novel because it lacks plot or theme, and its over-indulgence in raw realism for its own sake, and the weak climax. ${ }^{20}$ It may be possible to concede some merit to these criticisms and still assert the remarkable ability of the writer in presenting some of the most brutal, inhumane episodes of the war in such a way as to engage the reader's attention in the totality of the surrounding story rather than in the horrors of the prison camp alone. MacKinlay Kantor is one of the few who could have brought

\footnotetext{
19 Helen Cowles LeCron, "Other Writers of Promise and Fulfillment," in $A$ Book of lowa Authors, pp. 240-244.

${ }^{20}$ W. J. Stuckey, The Pulitzer Prize Novels, pp. 175-180.
} 
off such a tour de force. The reader is made to experience the whole horrendous reality of this historical nightmare from inception to completion; he may be revolted, but having learned the truth he would never again be satisfied with anything less than the truth. Kantor persuades the reader that "it could happen here" because of the military system: when those in authority act, they must not be overruled lest the whole chain of command be called into question.

After this triumph, Kantor plunged immediately into the research necessary for a similar treatment of lowa's most famous story, the Spirit Lake Massacre of 1857. Five years of unrelenting work went into the making of Spirit Lake (1961). Like Andersonville, this enormous book is a mixture of history and fiction, made credible by the fullness and accuracy of detail. The author built up for his use a staggering amount of information about the region, the Sioux Indians, and the white "imperialists" who had exposed themselves needlessly by pushing too far and too fast into the Indian country. He challenges the familiar story of Inkpadutah's revenge motive by asserting that he and Chief Sidominadotah were not brothers but members of two entirely different branches of the Sioux nation, the one a Wahpekute, the other a Sisseton.

\section{Other Recent and Contemporary Novelists}

Several well known authors of fiction remain to be noticed; the brevity of treatment of some of them is not to be taken as a gauge of their importance as writers. Some of these lowans preferred to live and work in other states; some escaped to parts as far away as possible. The names of Thomas Beer (1889-1940) and James Norman Hall (1887-1951) come to mind in this connection. The former was born in Council Bluffs and grew up there, attending the public schools in preparation of college. His choice fell on Yale University, followed by the study of law at Columbia University. Although nominally engaged in the practice of law, he was far more active as a man of letters than as a barrister. The author of three run-of-the-mill novels, and many short stories, he is far better known as a biographer of Stephen Crane (1923) and Marcus Alonzo Hanna (1929), and for his brilliant essay on the 1890s, The Mauve Decade (1926).

James Norman Hall was born in Colfax where the prosaic 
surroundings of his youth ${ }^{21}$ completely belied the excitement and wide range of his later experiences. After graduation from Grinnell College in 1910 he saw very little of lowa except on nostalgic occasions such as college reunions, nor do his writings deal with the lowa scene. Before the United States entered World War I he offered his services to England and saw some heavy fighting in Belgium, all of which he described in Kitchener's Mob (1916). Next, he gave up a war correspondent's job to become a flyer for France in the Escadrille Lafayette, a thrilling experience which he recounted in High Adventure (1918). After America's entry into the war he transferred to the American Expeditionary Forces in February, 1918, and became Captain Hall and a combat flyer. Three months later he was forced down behind German lines and captured, and did not gain release until after the Armistice. His unusual war experiences showed up in two books written after the war with Charles Bernard Nordhoff, a fellow American in the Escadrille.

The much decorated flyer returned to the United States in 1919 and attempted the orthodox role of writer and lecturer but failed to carry it off. Escape in the form of a trip to the South Seas with his friend, Nordhoff, made possible the inevitable travel book, Faery Lands of the South Seas (1921). Returning to Grinnell College for a class reunion, his less rootless classmates and friends honored him with election to the presidency of the Alumni Association, a position which did not tie him to lowa. Another fling at travel, this time to Iceland for a very unhappy year, yielded only an article and the firm resolution to return to the South Seas. Escapism was now a way of life for him; where others of his way of thinking became the "lost generation" in Paris, he preferred the softness and ease of living in Tahiti, a modern Epicurean of the truest sort. In 1925 he married an English girl and settled down for an indefinite stay in Tahiti. An occasional magazine article for Woman's Home Companion, Travel, or The Atlantic Monthly sufficed to pay the bills. Reunited with his writing partner, Nordhoff, the two relived their war years by writing Falcons of France, and then their masterpiece, Mutiny on the Bounty (1932), a fictional account of an episode in British naval

\footnotetext{
${ }^{21}$ Hall satirized this aspect of his youth in a delightful spoof written under the pseudonym of "Fern Gravel," O Millersville (Muscatine: The Prairie Press, 1940).
} 
history. This success was followed by three other books to make up the Bounty series, all deservedly popular but none achieving the quality of the first. The two friends collaborated on a dozen books before Nordhoff's death in 1947; Hall died in Tahiti in 1951. ${ }^{22}$

During the 1930s the most popular lowa author was almost certainly Philip ("Phil") Duffield Stong of Keosauqua. State Fair, his best known book, was the story of the experiences of an lowa farm family-father, mother, son, daughter-at the annual extravaganza in Des Moines where they went to exhibit their Hampshire boar, Blue Boy, winner of the best of breed and sweepstakes prizes, so it turned out. More important were the things which happened to the boy and his sister.

For many years the book was banned from the author's home town library because of its oblique reference to sex; now the book seems incredibly naive, deserving of its banishment to oblivion. Writing in 1951, John T. Frederick called it a mixture of romanticism and realism, the former very bad and the latter very good; a more recent critic calls State Fair and Stong's other books mere "light fiction exercises," a "long succession of cheerful rural idylls" which "make no serious effort to come to grips with social or economic problems," leaving the reader with a final impression of "gay inconsequence." 23

Thomas Duncan (1905- ), once thought of as a writer of considerable promise, apparently reached his peak with the writing of Gus the Great (1947), a Book-of-the-Month Club selection which assured vast sales and also the sale of film rights. A native of Casey, lowa, a town which shows up under many names in his various writings, and formally educated at Drake and Harvard, with practical experience as a writer for the Des Moines Register and as a teacher at Drake and Grinnell, he utilized his flair for acting and his love of Shakespearean plays for the writing of his first novel, $O$, Chautauqua (1935), an insight into the kind of intellectual fare which was served up to lowans and other Americans in the early 1900s. His love of the circus and his discovery that a circus had once had winter quarters in

${ }^{22}$ Ruth A. Gallaher, "James Norman Hall," in A Book of lowa Authors, pp. 125-134; Annals of lowa, 31 (October 1951), 158-159; information from Mrs. Mary E. Klausner, Archivist, Grinnell College.

${ }^{2}{ }^{3}$ Roy W. Meyer, The Middle Western Farm Novel, pp. 94-99; New York Times, April 28, 1957; Des Moines Register, February 7, 1965. 
Granger, lowa, near Des Moines, led to the writing of his major work, Gus the Great. Since the middle ' 40 s he has lived in the West and apparently cut all ties with lowa. His later novels have not enhanced his reputation.

Charlton Laird, a native of Nashua, with degrees from the University of lowa and Stanford in English, has for many years taught at the University of Nevada. He has divided his time between technical pedagogical writings and historical fiction. The career of the Indian, Black Hawk, has intrigued him and claimed much of his attention, as his excellent novel, Thunder on the River (1949), well demonstrates. Another excellent novel, West of the River (1953), pursues the frontier theme.

Richard P. Bissell of Dubuque, who forsook the business world to take on the hazards of a writing career, has experienced the satisfaction of proving that he could make a place for himself in the writer's world. His gift of ironic humor enables him to function as a social commentator without becoming didactic. Two novels, $7-1 / 2$ Cents, and Say, Darling were turned into musical comedies for the stage and movies but his work has a more serious vein. A Mississippi River buff, houseboat owner, and sometime working hand on a barge, his articles and books about life on the river reek with realism. A Stretch on the River (1950) is his most serious work; the others seem to have been written with tongue in cheek while making their points.

Frederick F. Manfred, earlier known as Feike Feikema, is an lowan of Frisian stock and so far has made good use of his bred-in knowledge of these unusual people who have settled in northwest lowa and over the line into Minnesota and the Dakotas, a region known as Siouxland. Born in this corner of lowa, near Doon, he has spent much of his time in other parts of Siouxland; he served for a time as Writer-in-Residence at the University of South Dakota. Critics find his novels vigorous and fully authentic but much too wordy, overly detailed, and over-dramatized.

Among current American writers, two lowans are outstanding: Curtis Harnack and Ronald Verlin Cassill. Harnack was born in Le Mars in 1927, studied at Grinnell College and Columbia University, and has taught at Sarah Lawrence College. He is best known for two novels, The Work of An Ancient Hand (1960) and Love and Be Silent (1962), and his fascinating account of his Fulbright year at the University of Tabriz, Persian Lions, Persian Lambs (1965). In 
addition he has several good short stories to his credit, and some excellent non-fiction articles in The lowan. The novels are laid against a farm-small town background; the careful attention to detail reminds one of Ruth Suckow's work at its best. His recently published autobiographical essay, We Have All Gone Away (1973), is a model of its kind. It places his own early years against a farm background in Remsen township, Plymouth County, and explains the authenticity of his novels. ${ }^{24}$

Ronald Verlin Cassill was born in Cedar Falls in 1919, the son of a public school teacher-administrator whose career took him to a number of towns in lowa. Ronald Cassill took his B.A. and M.A. degrees at the University of lowa. Thoroughly "Iowan" by birth, residence, and training, it is nevertheless difficult to discover lowa influences in his work. After two periods of teaching in the Writer's Workshop at the University of Iowa (1948-1952 and 1960-1966), and some time as Writer-in-Residence at Purdue Universtiy, he moved to Brown University where he currently teaches. In 1966 he received the Blackhawk Award given by the Midland Booksellers Association for the best book by an lowa author in 1965, the honored volume being The Father and Other Stories. ${ }^{25}$ Besides his novels, The Eagle on the Coin (1950), Clem Anderson (1961), Pretty Leslie (1963), and The President (1964), there are many short stories to his credit, especially "The Happy Marriage" (1966), and a book of essays, In An Iron Time: Statements and Reiterations (1969).

\section{lowa Poets}

lowa has produced and nurtured many poets, certainly enough to offset any notion that its people are devoted exclusively to materialism. Major S. H. M. Byers, the Civil War poet, John L.

${ }^{24}$ Information kindly supplied by Mrs. Mary G. Jones, Alumni Secretary of Grinnell College; Roy W. Meyer, The Middle Western Farm Novel, pp. 171-173; Paluka, lowa Authors, pp. 95-104. See the review of We Have All Gone Away, by Julie McDonald, in Annals of lowa (Winter, 1974), pp. 297299.

${ }^{25}$ See Paul Engle (ed), Midland: Twenty-five Years of Fiction and Poetry Selected from the Writing Workshop of the State University of lowa (New York: Random House, 1961), pp. 583-584; Paluka, lowa Authors, pp. 235-237; Des Moines Register, June 19, 1966. Ronald V. Cassill, The Happy Marriage and Other Stories (Purdue University Studies, edited by George P. Elliott, 1966), pp. 7-11, gives a helpful introduction to Cassill and his philosophy. 
McCreary, a hack journalist who rose above mediocrity in his poem, "There Is No Death," and Leonard Brown of Des Moines, ${ }^{26}$ the poet-populist of the late 19th century, gave lowans a few examples of above-average poetry though nothing worthy of more than passing mention. The young Hamlin Garland made some attempts at poetry before settling on prose as his medium; in her youth Octave Thanet likewise divided her time and her interests between poetry and prose; Herbert Quick was another to try his hand at poetry. Several later writers such as Ruth Suckow and MacKinlay Kantor began their writing careers as poets but turned to prose fiction.

The first to establish himself as a serious poet was an adopted lowan, Edwin Ford Piper, a Nebraskan by birth and training with the addition of some years at Harvard. He reached the peak of his abilities while a professor at the University of lowa from 1905 until his retirement in the 1930s. His first book, Barbed Wire and Other Poems (1917), came from the Midland Press, an adjunct to John T. Frederick's journal, The Midland, after some of the poems had first been published in the journal. While his theme was the familiar one of the coming of the settlers to the West, primarily to Nebraska, his material constitutes a commentary on the whole region, including his adopted state. ${ }^{27}$

Who are the major lowa poets?At least three seem to deserve this rating: Arthur Davison Ficke (1883-1945), Paul Engle (1908--, and James Hearst (1900--.

\section{Arthur Davison Ficke}

Born into a wealthy and influential German-American family in Davenport, young Arthur Ficke was graduated from Harvard in 1904, studied law at the University of lowa, and in 1908 joined his father's law firm, probably with the intention of making the law his lifelong career. Even so, by this date he had found time to write and publish three volumes of first-rate poems, and he continued to divide his time and interest between his profession and his first love. While serving as an officer in the American Expeditionary Forces in France in 1918 he received a letter from his father informing him of a large

\footnotetext{
${ }^{26}$ Louella M. Wright, "Leonard Brown-Poet and Populist," lowa Journal of History and Politics, 46 (July, 1948), 227-265.

${ }^{27}$ Alice C. Weitz, "Edwin Ford Piper," in A Book of lowa Authors, pp. 149-159.
} 
gift of money and his release from membership in the family law firm. Now he was free to live in the city of his choice, New York, to travel, to consort with friends of kindred tastes, and to devote all of his attention to his love of poetry and the arts. A man of highly refined and exquisite tastes, widely travelled in Europe and the Far East, with a special affinity for Japanese art, his poetry was much too esoteric for the man of average tastes but highly valued by those who were prepared to read him with full understanding. ${ }^{28}$

\section{Paul Engle}

If lowa has an unofficial poet laureate it is undoubtedly Paul Engle, presently Director of the International Writing Program at the University of lowa. In addition to his career as a poet and teacher, he has in recent years made another career of finding funds for fellowships and outright grants to young writers, thus providing beginning writers in the various Writer's Workshops at the Universtiy with the freedom to experiment and to write at their own pace. Fortunately, these fund-raising efforts have found generous donors, and, happily, many recipients of assistance have gone on to success, some to fame, enough of them to make the whole undertaking extremely worthwhile.

Paul Hamilton Engle was born in Cedar Rapids in 1908. He attended Coe College, received a master's degree from the University of lowa in 1932, studied briefly at Columbia, and went on to Oxford University on a Rhodes Scholarship. His books include West of Midnight (1941), American Child (1945), The Word of Love (1951), and Poems in Praise (1959). Two novels should be added to the list: Always the Land (1941) and Golden Child (1962), the latter based on his libretto for an opera by the same title, the music by Paul Bezanson, a colleague at the University. ${ }^{29}$

\section{James Hearst}

In an essay published in 1930, Helen Cowles LeCron, editor of the book page of the Des Moines Register, made the cautious

\footnotetext{
${ }^{28}$ Paluka, lowa Authors, pp. 74-77; Lewis Worthington Smith, "Arthur Davison Ficke," in A Book of lowa Authors, pp. 57-67; Charles August Ficke, Memories of Fourscore Years (Davenport: Graphic Services, 1930), p. 459.

29 Paluka, lowa Authors, pp. 214-216; Des Moines Register, July 17, 1970; Paul Engle (ed.), Midland: Twenty-five Years of Fiction and Poetry, pp. xxi-xxxvii.
} 
prophecy, that of the several young lowa poets then showing promise, she had the greatest hopes for two who just then were coming into public notice, James Hearst of Cedar Falls and MacKinlay Kantor of Webster City. Four decades later it can be said that Mrs. LeCron's literary judgment has been amply vindicated, Kantor as a novelist, however, rather than as poet. Her one reservation about Kantor was that he might be "led astray by a too great facility," and her one quibble concerning James Hearst was that his verse was a bit too "reminiscent" of Robert Frost. ${ }^{30}$ Neither judgment would be sustained today.

Although he has published a few short stories, James Hearst has clung to the short poem as his preferred medium. The story of the discovery of his talent is an interesting one. A near fatal swimming accident on Memorial Day, 1919, forced him to give up his last two years at lowa State Teachers College (University of Northern Iowa) and spend a long recuperative period in the University of lowa Hospitals, during which time his native bent towards literature, sharply awakened in the classes of Professor William Brock Fagan, reasserted itself. Through friends a contact was made with Professor John T. Frederick, mentioned above, who gave encouragement and advice, and as mentor and friend became perhaps the greatest single influence on Hearst's career. The young apprentice reciprocated Professor Frederick's assistance by serving a term as a reader of manuscripts for The Midland. In 1926 his own first published work appeared in that journal in the form of a group of short poems.

The covering biographical notes in The Midland simply said: "James Hearst is a young writer of Cedar Falls, lowa, who divides his time between writing and farming." This simple and disarming sentence contains a wealth of meaning. Born and reared on Maplehearst Farm, near Cedar Falls, Jim and his brother, Charles J. Hearst, were given full management of the corn-cattle-hog operation on the 520-acre family farm during their father's presidency of the lowa Farm Bureau Federation, 1923-1936, which required his presence in Des Moines or Washington most of the time. In spite of his physical handicap, Jim was able to assume a large share of work, riding a tractor for hours on end during the busy seasons, and

\footnotetext{
${ }^{30}$ Helen Cowles LeCron, in $A$ Book of lowa Authors, pp. 237-249, especially 243-244.
} 
participating in the bookkeeping and decision-making process during these parlous times for agriculture. Therefore, his stance as a farmer-poet was not an idle pretense; the titles of his books, Country Men (1937), The Sun At Noon (1943), Man and His Field (1951), Limited View (1962), and A Single Focus (1967), are sincere reflection of his love of the land. ${ }^{31}$

Though now a resident of Cedar Falls in order to carry on his work as a faculty member at the University of Northern lowa, offering courses in creative writing and other subjects in the Department of English, his interest in the farm and in farming has never waned. As a departmental colleague has put it:

The personal friends of James Hearst have often remarked the intimate relationship of the man and his poetry.... We have poets who have retired to farm-life, men who have described what they have seen and felt. But seldom have we had poets who have felt first as farmers, later to write as poets. The difference is authenticity. ${ }^{32}$

One searches his poems for a particular favorite for quotation to show his style, his meaning, his grasp of life-and ends up wanting to quote all of them. Any slight resemblance to the style of Robert Frost is traceable to the kindred natures and intimate friendship of the two men, a friendship expressed by many visits by Frost to the Hearst homes in lowa. Frost himself once referred to a resemblance between some of Hearst's poems and the Spoon River Anthology, while the lowa poet avers that his principal debt is to John Millington Synge! ${ }^{33}$

\section{Mona Van Duyn}

Added to these three names should be that of Mona Van Duyn, a poet of lowa backgrounds, now teaching at Washington University, who has recently acquired a national audience. Born in Waterloo in 1921, she is a graduate of the University of Northern lowa and the University of lowa, where she worked in the Poetry Workshop. Her

${ }^{31}$ Robert Frost, Selected Letters of Robert Frost, edited by Lawrance Thompson (New York: Holt, Rinehart and Winston, 1966), pp. 499-500; H. Willard Reninger, "James Hearst: A Country Man As Poet," in Man and His Field (Denver: Alan Swallow, 1951), pp. 9-15; Ruth Suckow, Foreword to Country Men, by James Hearst (Muscatine: The Prairie Press, 1937); The lowan, 12 (Fall, 1963), 11-13; The Midland, 12 (August, 1926), 237-239.

${ }^{3} 2$ Reninger, "James Hearst," p. 9.

${ }^{33}$ Frost, Selected Letters, p. 500; James Hearst's statement to the author. 
first book of poems, Valentines to the Wide World (1959), was privately printed; her next, $A$ Time of Bees (1964), was accepted for publication by the University of North Carolina Press; and her latest, To See, To Take (1970), by Atheneum (New York). Many of her poems have won prizes as individual pieces; in March, 1971, came the crowning distinction when it was announced that her 1970 collection, To See, To Take, had been awarded the National Book Award for poetry. ${ }^{34}$

\section{lowa Painters}

Difficult as it is to write about artists and their works without accompanying illustrations or originals, at least brief mention should be made of a few lowa painters whose careers show the same transition from romanticism to realism which marks the history of literature. George Henry Yewell (1830-1923), a Marylander by birth, was only eleven years old when brought to lowa City where he grew up with the territorial-state capital. He remained there until well after the Civil War and considered it his home until late in his long life when he settled in the East. Largely self-taught in his early years, his abilities were sufficient to attract the attention and limited sponsorship of William Penn Clarke, the eminent attorney and editor, and Hugh D. Downey, banker and real estate agent, both of lowa City. Numerous letters in the Clarke Correspondence tell of his ambition and his struggles as he fought for a chance to study in New York, and later in Paris and Rome. Portraiture was his forte and many examples of his work, all in the romantic style, are to be found in the halls of the lowa State Historical Building. ${ }^{35}$

A transitional figure is Charles Atherton Cumming, who came to lowa from Chicago as a young man in 1880 to teach art at Cornell College; after fifteen years there he moved to Des Moines and taught privately until 1908 when he was called to the University of lowa to create and head up an art department. He was able to do this and

${ }^{34}$ New York Times, March 5, 1971; April 4, 1971; Des Moines Register, April 11, 1971.

${ }^{35}$ Yewell to William Penn Clarke, August 31, 1852; February 19, 1858 (William Penn Clarke Correspondence, lowa State Department of History and Archives, Des Moines); Oneita Fisher, "George Henry Yewell, Early lowa Artist," The lowan, 15 (Winter, 1966-1967), 40-43, 52. 
continue his studio teaching in Des Moines by dividing his time between Des Moines and lowa City. He was an excellent painter as well as a teacher of immense influence, with a great gift for stirring up interest in the fine arts. He retired from teaching in 1926 and died in $1932 .{ }^{36}$ Surely this adopted son of lowa did enough for his state to be accepted as a full-fledged lowan.

Marvin Cone (1891-1965), a native of Cedar Rapids, and Grant Wood (1892-1942) are often linked as friends of Cedar Rapids high school days, though their backgrounds were quite disparate. Cone was a Cedar Rapids native whose family was comfortably fixed; Wood was born on a farm near Anamosa and moved to Cedar Rapids with his widowed mother to spend many years of penurious existence. Cone attended Coe College and later studied at length in New York and in Europe; Wood could not attend college and was able to manage only brief periods of formal study in Minneapolis, Chicago, Paris, and Naples. Wood became far more famous internationally and was more of an individualist-in a sense, he had to be if he were to stay alive. Desperately poor, one wonders how he and his sister and their widowed mother survived the hardships of his early years as a painter and craftsman. Somehow, by dint of great sacrifice and through help of loyal friends, he managed to exist until a definite style could emerge and his works could become salable. After flourishing for a while in a Cedar Rapids studio, he was appointed to a teaching post and later the headship in the Department of Art in the University of lowa. A notable feature of his career was the summer art colony which he established and directed at Stone City near Anamosa. At lowa City his life had its seamy side as well as its pleasures; not all his colleagues endorsed the appointment of this maverick to the sacred halls of ivy, and some openly fought his retention in academe. Early death from cancer at the age of 50 relieved the tenseness of the situation. ${ }^{37}$

${ }^{36}$ Bess Ferguson, "Charles Atherton Cumming-Art Was His Legacy," Des Moines Sunday Register, October 1, 1972; Also see Bess Ferguson with Velma Wallace Rayness and Edna Patzig Gouwens, Charles Atherton Cumming, lowa's Pioneer Artist-Educator (lowa Art Guild, 1972).

${ }^{3}$ Darrell Garwood, Artist in lowa: A Life of Grant Wood (New York: W. W. Norton \& Co., 1944), passim; Norma Jane Langford, "The Stone City Colony," The lowan, 13 (Spring, 1969), 41-44, 52-53, invaluable for the photographs of Grant Wood and his friends; Grant Wood, Revolt Against the City (Iowa City; The Clio Press, 1935), a slender volume highly reminiscent of Hamlin Garland's earlier plea for midwesterners to write or paint their own 
lowans, and Americans in general, owe it to him to discover that he painted dozens of good pictures other than American Gothic. In the meanwhile his friend Marvin Cone was pursuing a steady and rewarding career as a teacher at his alma mater and as a painter in his own right.

Almost every town and city in lowa would seem to have one or more artists of local, or even statewide reputation-artists who exhibited regularly in regional shows and at the lowa State Fair, as Grant Wood himself did for several years. One of the most typical and successful of these was Jessie Parrott Loomis (1912-1966) of Waterloo, the winner of many awards. As one would expect, the college and university towns of the state have some advantage over other locations in attracting artists to their midst. A number of college teachers have done valiant work in raising the standards of appreciation and understanding; one thinks at once of Karl Mattern of Drake University (1893-1969), James Lechay, Byron Burford, and Mauricio Lasansky at the University of lowa, and John Page at the University of Northern lowa. For many years, until his tragic death in 1970, George Shane, the very able art critic of the Des Moines Register, and himself an excellent painter of lowa scenes, was a gentle and tactful crusader for the recognition of the good things that were happening in lowa art circles. The well-administered museums under varying local names in Des Moines, Davenport, Marshalltown, Muscatine, Sioux City, Cedar Rapids, Mason City, and Waterloo supplement the educational work of the schools and colleges. The magnificent Owen Elliott collection recently donated to the University of lowa Museum is a treasure of infinite value and importance. ${ }^{38}$

Contributions by lowans to science have not been attempted in this short article because of the paucity of collected material. There is a definite need for an adequate short history of this important

regional themes. A recent tribute by a friend is "A Grant Wood Sampler," by Edwin B. Green, in The Palimpsest, 53 (January 1972), 1-32. On Marvin Cone, see Hazel Brown, Grant Wood and Marvin Cone (Ames: lowa State University Press, 1972).

${ }^{38}$ J. K. Brown, "Karl Mattern," The lowan, 14 (Winter, 1965-66), 33-35, 50; George Shane, "Exhibit of Beautiful Midwest," (on Jessie Parrott Loomis), Des Moines Register, January 13, 1968; John L. Zug, "Warm Welcome for a Glittering Gift," The lowan, 17 (Summer, 1969), 2-4. 
subject; one which would properly describe the contributions of lowans in the field.

Certain broad generalizations emerge from the foregoing survey of lowa writers and painters. Without being parochial, they have in the main used materials at hand, employed themes which are sprung from the region, and at the same time availed themselves of technical knowledge of universal origins. The universities and colleges have furnished basic instruction and inspiration, and nurtured the talents that sought their ministrations.

Finally, lowa's agriculture and urban industry have contributed a material wealth which aided the cause of writers and painters. There are many who can attest the generosity of state government itself, adding to that of the Fishers, the Cowles, the MacNiders, the Edmondsons, the Hubbells, the Elliotts, the Stephens, and the Carvers, and their counterparts in many towns and cities, with additional gifts from the large and small corporations, which have made possible the museums, the art collections, the travelling collections and libraries, the works by performing artists, the scholarships and grants, the building of theaters and concert halls, the attention given to architecture. Surely, proportionate to her population and her wealth, lowa has furnished tangible proof of a belief that bread alone is not enough if people are to live a full and sufficient life.

The Star Spangled Banner, by Peter Spier, Doubleday, 1973, 48 pages, $\$ 5.95$.

Peter Spier, who has established himself over the last fifteen years as one of the most gifted illustrators in this country, gives us a marvelous commemoration for America's upcoming Bicentennial celebration in this book. To the words of the national anthem Spier has set illustrations in full color.

As in other Spier books, inspiration has been backed up by careful research, so that every detail bears the mark of authenticity. A reproduction of the original Francis Scott Key manuscript and the music to the song with piano and guitar chords are included. 
Copyright of Annals of Iowa is the property of State of Iowa, by \& through the State Historical Society of Iowa and its content may not be copied or emailed to multiple sites or posted to a listserv without the copyright holder's express written permission. However, users may print, download, or email articles for individual use. 